\title{
Heat Loading of Steam Boilers Heating Surfaces
}

\author{
Mária Čarnogurská ${ }^{1}$, Miroslav Př́íhoda ${ }^{2}$, Blanka Skočilasová ${ }^{3}$, Bystrík Červenka ${ }^{1}$ \\ ${ }^{1}$ Faculty of Mechanical Engineering, Technical University of Košice, Vysokoškolská 4, 04200 Košice, Slovak Republic, \\ E-mail: maria.carnogurska@tuke.sk,bystrik.cervenka@tuke.sk \\ ${ }^{2}$ Faculty of Metallurgy and Materials Engineering, VŠB - Technical University of Ostrava, 17. listopadu 15, 70833 \\ Ostrava-Poruba, Czech Republic, E-mail: miroslav.prihoda@vsb.cz \\ ${ }^{3}$ Faculty of Production Technology and Management, J. E. Purkyně University in Ústí nad Labem, Na Okraji 1001/7, 400 \\ 01 Ústí nad Labem, Czech Republic, E-mail: skocilasova@fvtm.ujep.cz
}

This paper deals with the comparison of an analytical solution of the temperature field of a steam boiler pipe membrane wall using a numerical method calculation in the COSMOS/M programme. The result analysis showed that analytical calculating methods which are limited to 1D and 2D task types can be used for the approximate calculation of temperature in the selected locations of the membrane wall. With these methods it is not possible to obtain a complex view of the heat loading of the entire membrane wall or of the stress conditions caused by the thermal and pressure effect of steam-water mixture in the wall pipes. The results of numerical simulations have provided a complex image about the temperature and pressure distribution in the entire membrane wall of a steam boiler taking into account the material properties.

Keywords: Boiler, Membrane wall, Heat flux

\section{Acknowledgment}

This paper was written with the financial support of project $K E G A \check{c}$. 003TUKE-4/2016, project EU the operational programme ITMS 26220220044 and SP2017/37-FMMI VŠB TUO.

\section{References}

[1] PATEK, M., MIČIAN, M., SLÁDEK, A., KADÁŠS, D. (2016). Numerical Analysis of T-Joint Welding with Different Welding Sequences. Manufacturing Technology, Vol. 16, No. 1, pp. 234-238. UJEP, Ústí nad Labem.

[2] KOZUBKOVÁ, M., KRUTIL, J., NEVRLÝ, V. (2014). Experiments of methane flames and explosion in a complex geometry. Combustion explosion and shock waves, Vol. 50, No. 4, pp. 374-380, Springer Verlag.

[3] SKOČILASOVÁ, B., SKOČILAS, J. (2015). Nusselt Number Criteria Equations in the Cross Flow over Single Tube. Manufacturing Technology, Vol. 15, No. 6, pp. 1043-1048. UJEP, Ústí nad Labem.

[4] NOSEK, R., HOLUBCIK, M., JANDACKA, J., VICIAN, P. (2016). Using of local heat sources with warm-water heat exchanger for combustion of wood biomass in low temperature heating systems, Key Engineering Materials, Vol. 688, pp. 59-64. Scientifi.Net.

[5] KONAR, R., MICIAN, M., PATEK, M., KADAS, D. (2016). Finite Element Modeling and Numerical Simulation of Welding at the Repair of Gas Pipelines with Steel Sleeve. Manufacturing Technology, Vol. 16, No. 2, pp. 360365. UJEP, Ústí nad Labem.

[6] NOSEK, R., HOLUBČÍK, M., PAPUČÍK, Š. (2014). Emission Controls Using Different Temperatures of Combustion Air. The Scientific World Journal, p.6, Roskvil Pike, Bethesda MD, USA.

[7] ČERNÝ, V., JANEBA, B., TEYSSLER, J. (1983). Steam boilers - Technical guide, No. 32. SNTL, Praha, (in Czech).

[8] KUČERA, V. (1970). Membrane walls of steam boilers. Research report. SES Tlmače, (in Slovak).

[9] INCROPERA, F. P. (2007). Fundamentals of Heat and Mass Transfer. John Wiley, New York.

[10] RÉDR, M., PŘÍHODA, M. (1991). Fundamentals of heat engineering. SNTL, Praha, (in Czech).

[11] HANÁK, D. (1992). Using of the Finite Element Method for Determination of Temperature Fields in One-sidedly Irradiated Pipe Wall of Steam Boilers. Energetika, Vol. 42, No. 2, p. 45, Praha (in Czech).

[12] WERNE, F. (1966). Betriebserfahrungen, konstruktive Details und Spanungsanalysen mauerwerkloser Zwangdurchlaufkessel. Energie, Vol. 5, p. 174. (in Deutsch). 